\title{
De tijd van het gezongen dagblad
}

(naar een bijdrage van Jan Huyghe in

'Bachten de Kupe', nr. 4, 1982)

\section{Herman Laitem}

\section{"In Fraaiken zit er poer"}

In de herfst van 1912 verscheen Sportwereld (de krant van Karel Van Wijnendaele) voor het eerst. Het ultieme duwtje daarvoor was ongetwijfeld de recente Tourzege van Odiel Defraeye. Zijn stunt overtuigde de marketeers dat Vlaanderen rijp was voor een sportblad. Het blad zou een enorme invloed hebben op de algemene leeswil, meer dan veel saaie schoollessen samen. Maar ondertussen bleef een dagelijkse krant een betrekkelijke luxe en was er nog enkele decennia (beperkte) ruimte voor het oude beroep van nieuws- en sportzanger.

\section{Gezongen dagblad}

Elke regio had wel een gezongen dagblad, dat op week- en jaarmarkten de passanten entertainde met tekstflyers en zang, met pancartes en stok. Achille Coppenolle ( ${ }^{\circ}$ Torhout, 15 oktober 1885), uit Roeselare, was zo'n begrip. Vijfendertig jaar verdiende hij de kost met populaire tekstpoëzie en zang, samen met zijn dochters Martha (van '24 tot '38), Marianne (van '38 tot '43) en Betty (van '43 tot '47). Accordeon spelen had hij zichzelf geleerd, zonder enige kennis van notenleer. Het volk van liedjeszangers stamde in de regel uit de volksklasse en had het financieel niet breed. Daarom wellicht dat Marianne de roeping van haar vader jaren verzwegen hield voor haar man en kinderen. Er viel weinig eer mee te halen op de sociale ladder.

Vreemd genoeg kwam Achille Coppenolle uit een welgestelde familie van boeren en paardenfokkers en werd de traditie er bij hem niet ingelepeld via overlevering. Zijn ouders hadden hem eerder een toekomst uitgestippeld als dokter of advocaat. Erg verguld waren ze dus niet met zijn keuze.

\section{Vliegende bladen}

Alles samen zijn van Coppenolle zeventig vliegende bladen bekend, samen goed voor 411 liederen. Het lied over Defraeye vormt allicht zijn primeur, want vroeger werk van hem is niet bekend. Misschien daarom dat de verzen nogal rammelen en de tekst zwak is. Maar veel tijd om zich te bekwamen kreeg hij daarna niet meer. Bij de inval van de Duitsers in 1914 ging hij op de vlucht, naar Normandië. Daarna probeerde hij in Poperinge zo creatief mogelijk rond te komen. 


\section{Zegepraal van Odiel Defraye in de Ronde van Frankrjk}

Vlaanderen die mag zich weder roemen

Het heeft ne sportman fel en koen

$J$ a deze held zal men hier noemen

Het is De Fraye, kampioen

Hij heeft nu het bewijs gegeven

Dat hij meer als een ander kan

Hij is den eersten voor gebeleven

Dat is een eere voor de man.

\section{Refrein}

Ja De Fraye, is nen sterke rijder Hij wint de ronde van Frankrijk Zeker is het eenen harden strijder Berg op berg af, door zand en slijk

Men ziet in Fraaiken zit er poer

Hij wint-den-toer.

Fraaike dat is een man die goed rijden kan Hij won deze toer, ja in Fraaiken zit er poer.

Men ziet De Fraye, is nen taaien $J a$, vele eer valt hem te beurt Men mag voor hem victorie kraaien Hoog op de harten niet getreurd In deze strijd komt hij zegepralen

Die Vlaamschen jongen spant nu den kroon

Ook vele prijzen komt hij behalen

Voor hem dit huldebetoon.

De Fraye heeft moedig gestreden Hij was blijmoedig en vol vuur In deze toer heeft hij nu gereden

Dertig kilometers in het uur

$J a$, in die streke van de bergen Is dat voorwaar eenen sterken klop Men kwam hem nog met nagels tergen Maar Fraaike bleef al aan de kop.

Dus eer en hulde aan De Fraye Hij die blijft steeds ons aller vriend Men mag voor hem victorie kraaien

Hij heeft die lauweren verdiend Fraaike, schep moed, houd 't hoofd opgeheven

Geld, eer en roem hebt gij opgedaan Gij wordt gevierd voor uw moedig streven $U w$ naam zal in 't geschiedboek staan 
De doorstart gebeurde pas echt in 1920 toen Roesbrugge werd opgeschrikt door een politieke moord na de verkiezingen. Onder impuls van zijn vrouw Urbanie Beauprez koos hij definitief voor het vak van marktzanger. Zij geloofde in hem als zanger en instant-dichter, en zag het gat in de markt (sic). Het draaide uit op een familiebedrijfje dat Oost- en West-Vlaanderen 'afdweilde' met de fiets, weer of geen weer, en het volhield tot na de tweede wereldoorlog.

\section{Moord \& passie}

Met de volkse zucht voor sensatie en drama viel nog een boterham te verdienen. Brute moorden, verhitte passies, zinnelijk overspel... ze gingen er in als zoete koek. Het enige nadeel was de korte levensduur. Het kwam er dus op aan snel een gekende melodie te lenen en het nieuwsfeit te berijmen. Dit ging vaak ten koste van de kwaliteit, een euvel waaraan ook de 'vliegende bladen' leden. Met de verkoop van die bladen moest de zanger de kost verdienen, op markten, processies en feesten, aan kerken en fabriekspoorten.

Vlak voor de Tweede Wereldoorlog verhuisde Coppenolle naar Lichtervelde, waar hij al onmiddellijk een vette kluif kreeg toen de gemeentesecretaris er met de botte bijl inging en zijn vrouw en vier kinderen uit de wereld hielp. Een dag later had hij al zijn bloederig verhaal klaar en in geen tijd verkocht hij drieduizend exemplaren. Een uitzonderlijk aantal voor die tijd. De één zijn dood.... 